Open Access

\title{
Concentration changes in gemcitabine and its metabolites after hyperthermia in pancreatic cancer cells assessed using RP-HPLC
}

HB Jin, L Lu, L Xie, JF Yang, XF Zhang and $S L M a^{*}$

\author{
* Correspondence: \\ shenglinma2018@163.com \\ Department of Gastroenterology, \\ Affiliated Hangzhou First People's \\ Hospital, Zhejiang University School \\ of Medicine, Hangzhou 310006, \\ China
}

\begin{abstract}
Background: Gemcitabine (2',2'-difluoro-2'-deoxycytidine;dFdC) is a first-line chemotherapy drug for pancreatic cancer. Recently, a synergistic anti-tumor treatment of $\mathrm{dFdC}$ and hyperthermia has achieved good clinical results, but there are few reports on the molecular mechanism influenced by hyperthermia. This study is an initial exploration of the effects of hyperthermia on changes in the concentration of $\mathrm{dFdC}$ and its metabolites in pancreatic cancer cells. The aim is to provide a theoretical basis for clinical detection and pharmacokinetic research.

Methods: PANC-1 cells at logarithmic growth phase were used as the experimental object. The MTT assay was performed to determine the half maximal inhibitory concentration $\left(\mathrm{IC}_{50}\right)$ of $\mathrm{dFdC}$. After PANC-1 cells were cultured in DMEM medium containing $I \mathrm{C}_{50} \mathrm{dFdC}$ and treated with hyperthermia at $41^{\circ} \mathrm{C}$ or $43^{\circ} \mathrm{C}$, changes in the concentration of $\mathrm{dFdC}, 2^{\prime}, 2^{\prime}$-difluorodeoxyuridine (dFdU) and difluorodeoxycytidine triphosphate (dFdCTP) in the cells were tested using an optimized reverse phase highperformance liquid chromatography (RP-HPLC) protocol.
\end{abstract}

Results: We found that $41^{\circ} \mathrm{C}$ and $43^{\circ} \mathrm{Chyperthermia} \mathrm{gave} \mathrm{rise} \mathrm{to} \mathrm{a} \mathrm{decrease} \mathrm{in} \mathrm{dFdC}$ and dFdU content. At $41^{\circ} \mathrm{C}$, the levels respectively fell to 9.28 and $30.93 \%$ of the baseline, and at $43^{\circ} \mathrm{C}$, to 24.76 and $57.80 \%$, respectively. The dFdCTP content increased by $21.82 \%$ at $41{ }^{\circ} \mathrm{C}$ and $42.42 \%$ at $43^{\circ} \mathrm{C}$.

Conclusion: The two heat treatments could alter the mechanism of $\mathrm{dFdC}$ metabolism in PANC-1 cells. The effect of $43^{\circ} \mathrm{C}$ hyperthermia is more significant. Our observations may be instrumental to explaining the higher anti-tumor efficacy of this combination therapy.

Keywords: Pancreatic cancer, Gemcitabine, Metabolite, Hyperthermia, RP-HPLC

\section{Background}

Pancreatic cancer is one of the most common types of malignant tumor. It is a leading cause of cancer-associated mortality worldwide, with a 5 -year overall survival rate of less than $5 \%[1,2]$. Recent studies have predicted that by 2030 , its fatality rate will rise to second place in the United States (after non-small cell lung cancer) [3]. Its incidence is also increasing annually. Tumor resection is the only available curative treatment, but approximately $80 \%$ of patients are ineligible for surgery due to an unfavorable

(c) The Author(s). 2019 Open Access This article is distributed under the terms of the Creative Commons Attribution 4.0 International License (http://creativecommons.org/licenses/by/4.0/), which permits unrestricted use, distribution, and reproduction in any medium, provided you give appropriate credit to the original author(s) and the source, provide a link to the Creative Commons license, and indicate if changes were made. The Creative Commons Public Domain Dedication waiver (http://creativecommons.org/ publicdomain/zero/1.0/) applies to the data made available in this article, unless otherwise stated. 
tumor location and/or metastases [4]. Chemotherapy and radiotherapy are applied to improve these poor results [5].

Gemcitabine $\left(2^{\prime}, 2^{\prime}\right.$-difluoro-2' -deoxycytidine; $\left.\mathrm{dFdC}\right)$, a pyrimidine nucleoside analog, is a cell cycle-specific anti-cancer chemotherapy drug approved by the US Food and Drug Administration (FDA). It has a broad spectrum of antitumor activity [6]. It is also an active radio-sensitizer [7]. A randomized trial proved it has greater clinical and survival benefits than5-fluorouracil [8]. However, there are still some problems in its clinical applications, such as its low response rate, the rate degradation of the active substance, and tumor resistance $[9,10]$. The chemotherapy using dFdC combined with albumin-bound paclitaxel has been approved internationally $[11,12]$ and could significantly prolong the median survival time, reduce side effects and improve the quality of life for patients [13]. However, the wide application of this regimen is mainly limited by the high price of albumin-bound paclitaxel.

Therapeutically applied hyperthermia uses physical heating to maintain the temperature of tumor tissues at $40-44^{\circ} \mathrm{Cfor}$ a period of time. It can lead to growth block or death of the tumor cells without damage to normal cells. Heat treatment has recently attracted more attention due to its remarkable biological efficacy in the treatment of tumors and the advantages of being painless, non-invasive and without side effects [14].

Several studies have consistently demonstrated that some chemotherapeutic agents possess a synergistic anti-tumor efficacy when combined with regional hyperthermia [15-18]. dFdC combined with hyperthermia has been widely used in clinical practice. The clinical results for $\mathrm{dFdC}$ used in hyperthermic intraperitoneal intraoperative chemotherapy (HIPEC) in patients with resectable pancreatic cancer appear very promising [19]. Hyperthermia can induce Hsp70 to inhibit the activation of nuclear factor kappa B (NF- $\kappa \mathrm{B})$, thereby increasing the toxicity on pancreatic cancer cells [20]. Past research also demonstrated that hyperthermia increased the arrest of $\mathrm{S}$ phase and the apoptosis of pancreatic cancer cells by causing the over-expression of heat-shock protein 27(Hsp27) [21].

It has now been recognized that the metabolic pathway of $\mathrm{dFdC}$ is similar to that of cytarabine [22]. $\mathrm{dFdC}$ is transported into the intracellular region via human equilibrative nucleoside transporters 1 (hENT1) [23, 24], and catalytically converted to dFdCmono-, di- and triphosphate by deoxycytidine kinase. These forms subsequently block ribonucleotide reductase and DNA synthesis [25, 26]. In addition, dFdC can undergo an irreversible deamination reaction under the action of cytidinedeaminase and generate the inactive metabolite $2^{\prime}, 2^{\prime}$-difluorodeoxyuridine (dFdU), which is excreted outside the cell later. Alternatively, dFdCMP produces difluoromonophosphate deoxyuridine via 2 '-deoxycytidine 5 '-monophosphate (dCMP) deaminase, and then creates dFdU [27]. Therefore, some methods for detecting the concentration of dFdC metabolites and studying pharmacokinetics have been established [28], among which reverse phase high-performance liquid chromatography (RP-HPLC) was the most efficient and sensitive [29-31].

There are few reports on the effects of hyperthermia on the metabolic mechanism of $\mathrm{dFdC}$ in pancreatic cancer cells, and related detection methods are urgently needed for further optimization of the treatment. In this study, we used reverse phase high-performance liquid chromatography (RP-HPLC) to test the concentration changes 
of metabolites in pancreatic cancer cells (PANC-1) after treatment with dFdC combined with hyperthermia. Furthermore, we made an initial exploration of the effects of hyperthermia on the metabolism. Our aim was to provide a reference for the study of its pharmacokinetic mechanism and clinical drug detection.

\section{Methods}

\section{Cell culture and hyperthermia pretreatment}

Stored PANC-1 cells (purchased from the Institute of Biochemistry and Cell Biology, Shanghai Institutes for Biological Sciences, Chinese Academy of Sciences) were thawed quickly in $37-40^{\circ} \mathrm{C}$ water. The cell fluid was centrifuged for $5 \mathrm{~min}$ at $1000 \mathrm{rpm}$ to separate the supernatant, which was then discarded. The precipitate was added to the culture medium, which was Dulbecco's modified Eagle medium (DMEM) containing 10\% fetal bovine serum and 1\% antibiotic, then mixed well by gentle blowing. Further centrifugation under the same conditions was used to separate the supernatant again. After the second precipitate was dissolved well in the culture medium, it was transferred into a $25-\mathrm{cm}^{2}$ cell culture flask and cultured in a saturated humidity incubator at $37{ }^{\circ} \mathrm{C}$ and $5 \% \mathrm{CO}_{2}$. The cells were digested with 0.25\% trypsin containing 0.02\% EDTA (Hangzhou Lanbao Biotechnology Service) when they reached $80 \%$ coverage of the bottom of flasks. They were then subcultured into a 24-well plate at a concentration of $\sim 2 \times 10^{5}$ cells $/ \mathrm{ml}$ in the above incubator. Those in thelogarithmic growth phase were selected as experimental subjects. To simulate the hyperthermia treatment, PANC-1 cells were incubated in a water bath at $41^{\circ} \mathrm{C}$ or $43^{\circ} \mathrm{Cfor} 1 \mathrm{~h}$.

\section{Determination of the appropriate concentration of dFdC via MTT assay}

Culture mediums based on DMEM were prepared under aseptic conditions with different concentrations of $\operatorname{dFdC}(2.5,5.0,10.0,20.0$ and $40.0 \mu \mathrm{g} / \mathrm{ml})$. PANC-1 cells were inoculated into 96-well culture plates in an incubator at $37^{\circ} \mathrm{C}$ and $5 \% \mathrm{CO}_{2}$. After the monolayer culture had covered the whole bottom of wells, the original culture medium was replaced with the above DMEM-based one. Cells from the blank control group were still cultured in the original culture medium. Simultaneously, the treated groups of $41^{\circ} \mathrm{C}$ and $43^{\circ} \mathrm{Chyperthermiawere} \mathrm{also} \mathrm{established.}$

After culture for $2 \mathrm{~h}$, the culture medium was discarded. The remains were washed with phosphate-buffered saline (PBS) 2 or 3 times, then MTT solution $(5 \mathrm{mg} / \mathrm{ml}, \mathrm{pH}$ 7.4) was added to all wells followed by an additional $4 \mathrm{~h}$ incubation. Then, the mixture was added to dimethyl sulfoxide solution along and shaken for $10 \mathrm{~min}$ on a shaker at a low speed to fully dissolve the crystals. Absorbance was measured with a Molecular Devices plate reader at $490 \mathrm{~nm}$. The cell growth inhibition ratio was calculated with the formula.

Cell growth inhibition $(\%)=\left(1\right.$-drug treatment $\mathrm{A}_{490} /$ control group $\left.\mathrm{A}_{490}\right) \times 100 \%$

\section{RP-HPLC detection of dFdC and its metabolites at different temperatures}

\section{Chromatographic conditions}

RP-HPLC was performed with a Shimadzu 20AT HPLC System with a Zhida N2000 Chromatography Workstation at Zhejiang University. The main column was an Agilent $\mathrm{TC}^{-\mathrm{C}_{18}}(2)(5 \mu \mathrm{m}, 4.6 \times 150 \mathrm{~mm})$ and the guard column was an Agilent $\mathrm{TC}^{-\mathrm{C}_{18}(2)}$ 
$(5 \mu \mathrm{m}, 4.6 \times 12.5 \mathrm{~mm})$. The mobile phase was acetonitrile $(0.01 \mathrm{M}$ ammonium acetate at $\mathrm{pH} 6.5$ and $2: 98 \mathrm{v} / \mathrm{v}$ ); the flow rate was $0.8 \mathrm{ml} / \mathrm{min}$; the column temperature was $30^{\circ} \mathrm{C}$; the UV detection wavelength was $268 \mathrm{~nm}$; and the injection volume was20 $\mu \mathrm{l}$.

\section{Preparation of stock and working solutions}

Stock solutions $(1 \mathrm{mg} / \mathrm{ml})$ of $\mathrm{dFdC}, \mathrm{dFdU}$ and $\mathrm{dFdCTP}$ were prepared by dissolving standard drugs in methanol and ultra-pure water, respectively, and were stored at $-20^{\circ} \mathrm{C}$ for further use. For the internal standard (IS), $3 \mathrm{mg} / \mathrm{ml}$ stock solutions of cefaclor were prepared by adding acetonitrile to the solute and mixing well. Working solutions (100 $\mu \mathrm{g} /$ $\mathrm{ml}$ ) of all the standards were prepared each time by diluting corresponding stock solutions in afore mentioned solvents.

\section{Isolation and purification of cell lysate}

The harvested cell lysate was blended with IS solution $(1.0 \mathrm{mg} / \mathrm{ml})$. Then $0.1 \mathrm{ml}$ chromatographic acetonitrile was added to the mixture. After it was centrifuged at 18,000 rpm for $5 \mathrm{~min}$, the upper organic phase was isolated and mixed well with $0.1 \mathrm{ml}$ n-hexane. After centrifuging again under the same settings, the components in the upper layer were removed. These isolation and purification procedures were repeated twice. The samples in the lower acetonitrile layer were further executed for RP-HPLC detection.

\section{Establishment of calibration curves}

Working solutions of $\mathrm{dFdC}$, $\mathrm{dFdUand} \mathrm{dFdCTP}$ were separately serially diluted in cell lysate from the control group to prepare 6 calibration solutions $(20.0,10.0,5.0,2.5$, 1.25 and $0.5 \mu \mathrm{g} / \mathrm{ml})$. After the isolation and purification pretreatment, all the target standards were examined in duplicate using the RP-HPLC assay. The average peak area was analyzed using the linear least square regression method. Calibration curves were generated simultaneously, with assessments of the correlation coefficient $\left(\mathrm{r}^{2}\right)$ and slope.

\section{Recovery and precision inspection}

Three different concentrations $(0.5,5.0$ and $10.0 \mu \mathrm{g} / \mathrm{ml})$ within the calibration range were prepared using standard working solutions to evaluate recovery and precision of this method. Each sample was tested and analyzed 5 times on the same day and on three consecutive days to determine intra- and inter-day precision, respectively. The percentage of recovered compound was also established from these quality control (QC) samples.

\section{Calculation of $L O D$ and $L O Q$}

For three target compounds, limit of detection (LOD) and limit of quantification (LOQ) were determined by dividing the standard deviation $(\sigma)$ of the Y-intercepts of different linear regression equations with slopes, applying the following relationship: $\mathrm{LOD}=3.3 \times \sigma /$ slope and $\mathrm{LOQ}=10 \times \sigma /$ slope . 
Table 1 Absorbance and cell inhibition ratios of different concentrations of $\mathrm{dFdC}$ combined with hyperthermia as assessed with the MTT assay

\begin{tabular}{|c|c|c|c|c|c|c|c|c|c|}
\hline \multirow{2}{*}{$\begin{array}{l}\text { Concentration } \\
(\mu \mathrm{g} / \mathrm{ml})\end{array}$} & \multicolumn{6}{|c|}{ Absorbance } & \multirow{2}{*}{$\begin{array}{l}\text { Average } \\
\text { value }\end{array}$} & \multirow[t]{2}{*}{ SD } & \multirow{2}{*}{$\begin{array}{l}\text { Inhibition } \\
\text { ratio (\%) }\end{array}$} \\
\hline & $37^{\circ} \mathrm{C}$ & & $41^{\circ} \mathrm{C}$ & & $43^{\circ} \mathrm{C}$ & & & & \\
\hline 0 & 0.692 & 0.637 & 0.854 & 0.802 & 0.768 & 0.708 & 0.744 & 0.079 & \\
\hline 2.5 & 0.594 & 0.601 & 0.713 & 0.612 & 0.524 & 0.584 & 0.605 & 0.062 & 18.67 \\
\hline 5.0 & 0.608 & 0.594 & 0.537 & 0.553 & 0.489 & 0.518 & 0.550 & 0.045 & 26.05 \\
\hline 10.0 & 0.336 & 0.337 & 0.484 & 0.506 & 0.417 & 0.358 & 0.406 & 0.075 & 45.35 \\
\hline 20.0 & 0.105 & 0.127 & 0.156 & 0.136 & 0.118 & 0.127 & 0.128 & 0.017 & 82.76 \\
\hline 40.0 & 0.089 & 0.091 & 0.062 & 0.055 & 0.042 & 0.048 & 0.065 & 0.021 & 91.32 \\
\hline
\end{tabular}

\section{Cell dosing and metabolite detection}

PANC-1 cells in the logarithmic growth phase were cultured for $2 \mathrm{~h}$ with DMEM containing $14.073 \mu \mathrm{g} / \mathrm{ml} \mathrm{dFdC} \mathrm{in} \mathrm{an} \mathrm{incubator} \mathrm{at} 37^{\circ} \mathrm{C}$ and $5 \% \mathrm{CO}_{2}$. Groups of $37^{\circ} \mathrm{Ccontrol}$ and $41{ }^{\circ} \mathrm{Cand} 43^{\circ} \mathrm{C}$ hyperthermia were established synchronously. The entire culture medium was discarded and the reproductive cells were washed once in the blank DMEM. The isolation and purification of samples was performed immediately after complete lysis of the cells using lysis reagent. Then, $20 \mu \mathrm{l}$ purified solution was subjected to RP-HPLC analysis. After the chromatograms of three drugs were acquired, their peak area ratios were substituted into the corresponding equations for the calibration curves to calculate the contents of $\mathrm{dFdC}, \mathrm{dFdU}$ and dFdCTP.

\section{Results and discussion}

\section{Optimal concentration of $\mathrm{dFdC}$ for combination with hyperthermia}

After treating PANC-1 cells with different concentrations of $\mathrm{dFdC}$ combined with both hyperthermia conditions $\left(41{ }^{\circ} \mathrm{C}\right.$ and $\left.43^{\circ} \mathrm{C}\right)$, changes in the absorbance and cell

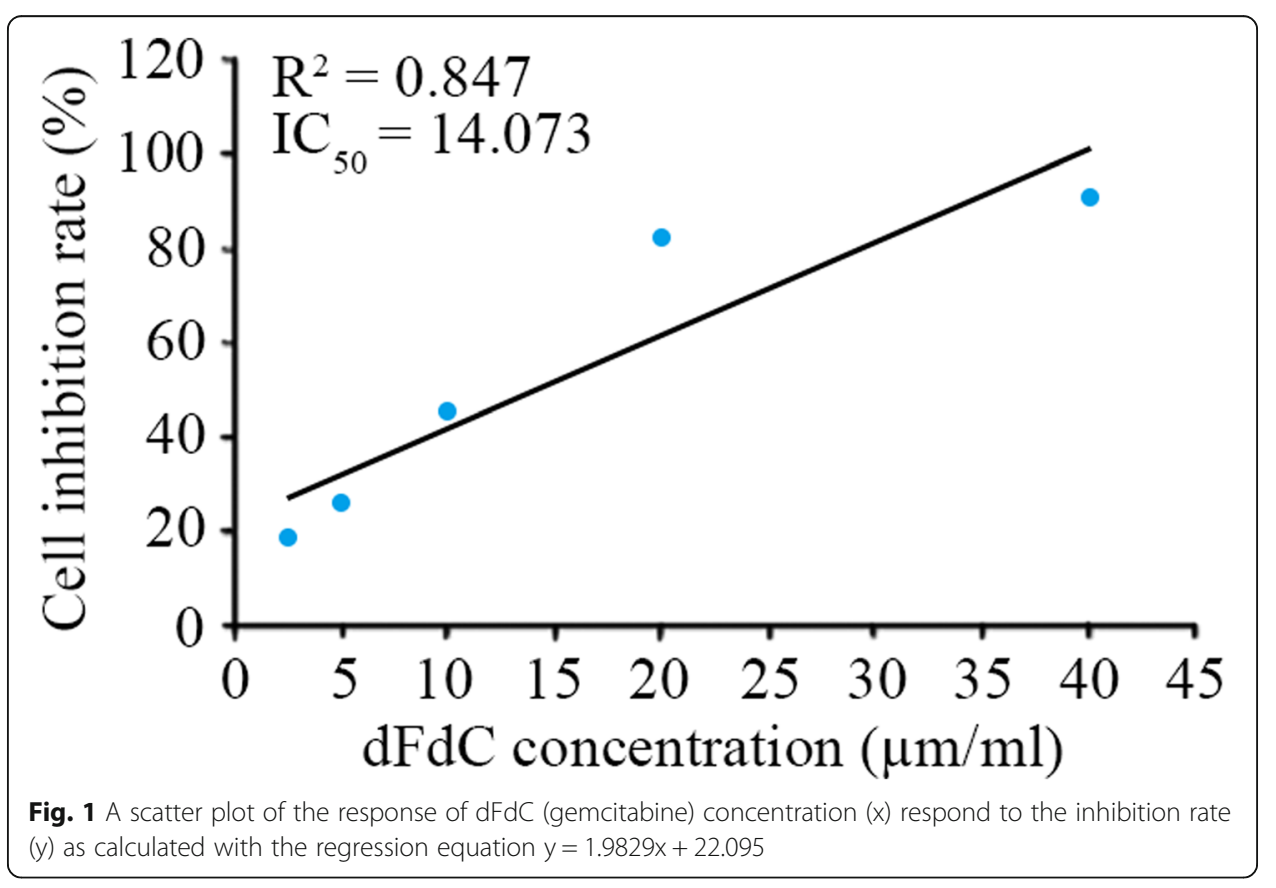




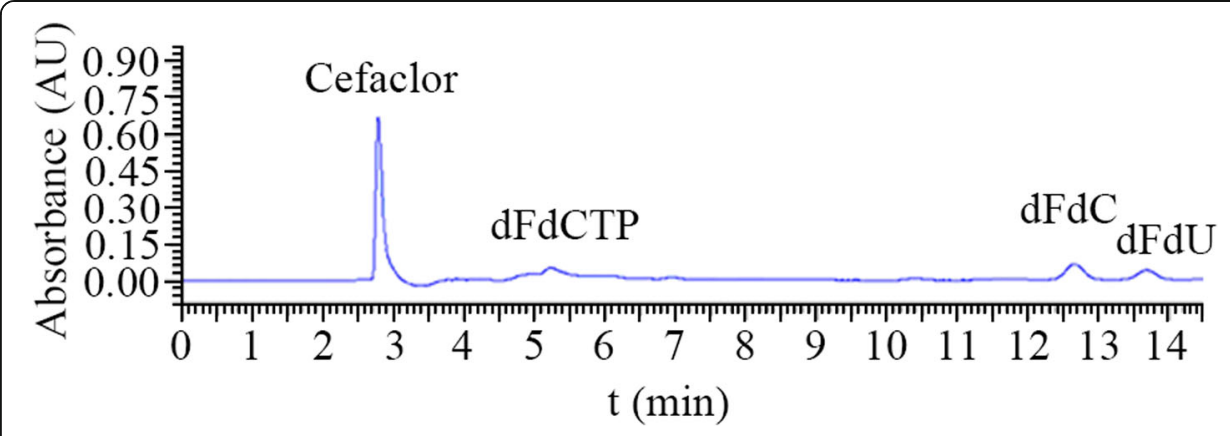

Fig. 2 Representative chromatograms of cefaclor (the internal standard), and dFdC, dFdU and dFdCTP at $268 \mathrm{~nm}$

inhibition ratios were assessed with the MTT assay (Table 1). Based on the linear regression analysis, the equation for the concentration $(\mathrm{x})$ and inhibition rate $(\mathrm{y})$ of dFdC was obtained (Fig. 1). When the cell inhibition was $50 \%$ (i.e., $\mathrm{IC}_{50}$ ), we calculated out the corresponding $\mathrm{dFdC}$ concentration $(14.073 \mu \mathrm{g} / \mathrm{ml})$. This concentration was applied to further study the metabolic process of $\mathrm{dFdC}$ combined with hyperthermia in PANC-1 cells.

\section{Optimization of the sample pretreatment process}

Many extraction reagents were assessed during the process of sample pretreatment. Methanol can precipitate proteins very well, but the supernatant obtained from the mixture showed trace proteins when stored at $4{ }^{\circ} \mathrm{C}$ overnight, which can lead to an increase in column pressure. Methylene chloride has the advantage of low $\mathrm{pH}$ and boiling point, but its solubility rate for $\mathrm{dFdC}$ and its metabolites was extremely low. The precipitation efficiency of trichloroacetic acid was the highest, but $\mathrm{dFdC}$ and its metabolites canbe decomposed heavily by this reagent. Acetonitrile enabled better precipitation of the target proteins, its solubility rate for $\mathrm{dFdC}$ and its metabolites was high, and it did not decompose them. Therefore, acetonitrile was recognized as the optimized choice.

\section{Characteristics of the internal standard and target chromatographic peaks}

Cefaclor was used as internal standard because of its stable and moderate retention time ( $2.744 \mathrm{~min})$ and good separation effect (Fig. 2). The chromatographic peak analysis shows that the retention times of $\mathrm{dFdC}, \mathrm{dFdU}$ and $\mathrm{dFdCTP}$ were about 12.401,

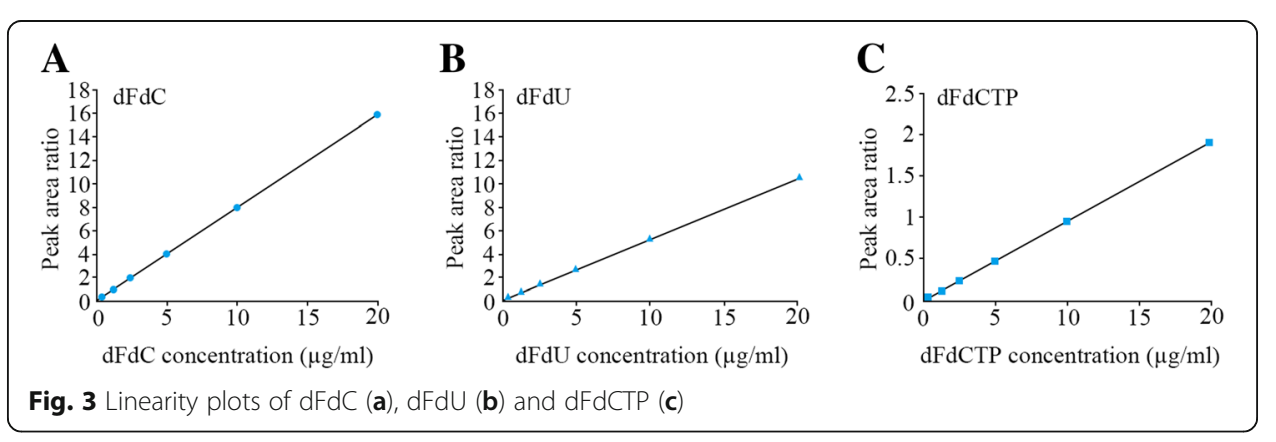


Table 2 Linear regression parameters of calibration equations for the standards

\begin{tabular}{llllll}
\hline Drugs & Analytical wavelength & Linearity $(\mu \mathrm{g} / \mathrm{ml})$ & Correlation coefficient $\left(\mathrm{r}^{2}\right)$ & Slope & Intercept \\
\hline $\mathrm{dFdC}$ & $268 \mathrm{~nm}$ & $0.5-20.0$ & 0.9999 & 0.7811 & 0.1209 \\
$\mathrm{dFdU}$ & $268 \mathrm{~nm}$ & $0.5-20.0$ & 0.9999 & 0.5112 & 0.0650 \\
$\mathrm{dFdCTP}$ & $268 \mathrm{~nm}$ & $0.5-20.0$ & 0.9998 & 0.0955 & 0.0014 \\
\hline
\end{tabular}

13.565 and $5.213 \mathrm{~min}$, respectively (Fig. 2). Their peak shapes were also complete with a favorable separation effect, and no interference peaks appeared.

\section{Linearity and range of calibration curves}

The average of peak areas of $\mathrm{dFdC}, \mathrm{dFdU}$ and $\mathrm{dFdCTP}$ was analyzed using least square linear regression as a function of analyte concentration. We found all drugs had a good linear relationship in the concentration range of $0.5-20.0 \mu \mathrm{g} / \mathrm{ml}$, with a correlation coefficient $\left(r^{2}\right)$ of $\geq 0.9998$ (Fig. 3). Several parameters of regression curves are displayed in Table 2, including their slopes and intercepts for all pure drugs.

\section{Precision and accuracy of the adopted method}

The precision of the given scheme was confirmed by analyzing QC samples at 0.5, 5.0 and $10.0 \mu \mathrm{g} / \mathrm{ml}$ for all target compounds. The results are expressed as \% RSD (Table 3 ). We found the range of intra-day variations was $1.42-5.17 \%$. The inter-day variations were smaller than $9.02 \%$ under different drug concentrations. In light of this, variations to this extent in the RP-HPLC method results were considered acceptable. Average accuracy observations revealed that this method was precise with a percentage recovery of $88.04-98.28 \%$. This met the detection criteria.

\section{LOD and LOQ of three standards}

According to the standard deviation of the Y-intercepts of the different calibration lines and two specified calculation formulas, LOD was found to be 0.2063, 0.3151and $1.6870 \mu \mathrm{g} / \mathrm{ml}$ for $\mathrm{dFdC}, \mathrm{dFdU}$ and $\mathrm{dFdCTP}$, respectively, while LOQ was $0.6250,0.9550$ and $5.1120 \mu \mathrm{g} / \mathrm{ml}$.

Table $\mathbf{3}$ Intra-day and inter-day precision and average accuracy

\begin{tabular}{lllll}
\hline Standard component & $\begin{array}{l}\text { Concentration } \\
(\mu \mathrm{g} / \mathrm{ml})\end{array}$ & $\begin{array}{l}\text { Average accuracy } \\
\text { (\%Recovery) }\end{array}$ & $\begin{array}{l}\text { Intra-day precision } \\
(\% \mathrm{RSD})\end{array}$ & $\begin{array}{l}\text { Inter-day precision } \\
(\% \mathrm{RSD})\end{array}$ \\
\hline $\mathrm{dFdC}$ & 0.5 & $94.71 \pm 0.03$ & 4.89 & 6.54 \\
& 5.0 & $93.49 \pm 0.05$ & 4.51 & 5.72 \\
& 10.0 & $98.28 \pm 0.02$ & 3.09 & 4.65 \\
$\mathrm{dFdU}$ & 0.5 & $88.04 \pm 0.07$ & 4.00 & 9.02 \\
& 5.0 & $90.91 \pm 0.04$ & 3.79 & 7.89 \\
$\mathrm{dFdCTP}$ & 10.0 & $96.08 \pm 0.11$ & 3.65 & 4.49 \\
& 0.5 & $90.86 \pm 0.03$ & 5.17 & 8.15 \\
& 5.0 & $93.85 \pm 0.06$ & 3.96 & 9.02 \\
& 10.0 & $95.60 \pm 0.08$ & 1.42 & 4.28 \\
\hline
\end{tabular}




\section{Concentration changes of $\mathrm{dFdC}, \mathrm{dFdU}$ and dFdCTP}

After the PANC-1 cells in the logarithmic growth phase were treated with $\mathrm{dFdC}$ combined with hyperthermia, the concentrations of $\mathrm{dFdC}$ and its metabolites had changed to some extent (Table 4, Figs. 4 and 5). In the groups of $\mathrm{dFdC}$ combined with $41{ }^{\circ} \mathrm{C}$ or $43{ }^{\circ} \mathrm{C}$ hyperthermia, dFdC was observed to decrease 9.28 and $30.93 \%$,respectively;dFdU showed a significant downward trend (i.e., 24.76 and 57.80\%); and dFdCTP increased 21.82 and $42.42 \%$.

Based on the above results, we believe that the two heat treatments could alter the metabolic process of $\mathrm{dFdC}$ in PANC-1 cells, with a greater effect from $43{ }^{\circ} \mathrm{C}$ hyperthermia. With regard to the decrease in $\mathrm{dFdC}$ content, one main explanation is that hyperthermia could promote the process of converting dFdC into its metabolites (e.g., $\mathrm{dFdCTP}$ ). In addition, we cautiously predict the decrease in dFdU content is most likely due to a reduction of the activity of cytidine deaminase (CDA) caused by hyperthermia, thereby inhibiting the direct and (or) indirect transformation from $\mathrm{dFdC}$ to $\mathrm{dFdU}$. It is known that dFdU is an inactive metabolite of irreversible deamination of dFdCTP [10], which occurs rapidly under the action of CDA, which plays an indispensable role in the detoxification of $\mathrm{dFdC}[32,33]$.

Surprisingly, $\mathrm{dFdC}$ combined with $43^{\circ} \mathrm{C}$ hyperthermia was more conducive to the production of $\mathrm{dFdCTP}$, which is an active ingredient produced by $\mathrm{dFdC}$ in cells after the action of deoxycytidine kinase (dCKs) and nucleoside kinase [34]. Relevant studies have shown that $\mathrm{dCKs}$ are the rate-limiting enzyme of $\mathrm{dFdC}$, and its activity is closely related to chemosensitivity [35]. Therefore, we speculate that hyperthermia increases

Table 4 Effects of hyperthermia on changes in the concentration of $\mathrm{dFdC}$ and its metabolites

\begin{tabular}{llll}
\hline & $\mathrm{dFdC}(\mu \mathrm{g} / \mathrm{ml})$ & $\mathrm{dFdU}(\mu \mathrm{g} / \mathrm{ml})$ & $\mathrm{dFdCTP}(\mu \mathrm{g} / \mathrm{ml})$ \\
\hline $37^{\circ} \mathrm{C}$ & 1.02 & 2.86 & 3.24 \\
& 0.91 & 3.65 & 3.25 \\
& 1.03 & 3.41 & 3.33 \\
& 0.90 & 2.91 & 2.89 \\
& 1.02 & 3.15 & 3.81 \\
Average value & 0.97 & 3.19 & 3.30 \\
Standard deviation & 0.063 & 0.33 & 0.34 \\
$41^{\circ} \mathrm{C}$ & 1.12 & 2.29 & 4.17 \\
& 0.97 & 2.57 & 3.92 \\
& 0.70 & 2.33 & 4.98 \\
& 0.94 & 2.52 & 3.37 \\
Average value & 0.66 & 2.31 & 3.68 \\
Standard deviation & 0.88 & 2.40 & 4.02 \\
43 ${ }^{\circ} \mathrm{C}$ & 0.19 & 0.13 & 0.61 \\
Standard deviation & 0.82 & 1.43 & 4.79 \\
\hline & 0.68 & 1.46 & 4.67 \\
& 0.64 & 1.14 & 4.76 \\
& 0.69 & 1.15 & 4.81 \\
& 0.55 & 1.52 & 4.46 \\
& 0.67 & 1.34 & 4.70 \\
& & 0.18 & 0.14 \\
\hline
\end{tabular}



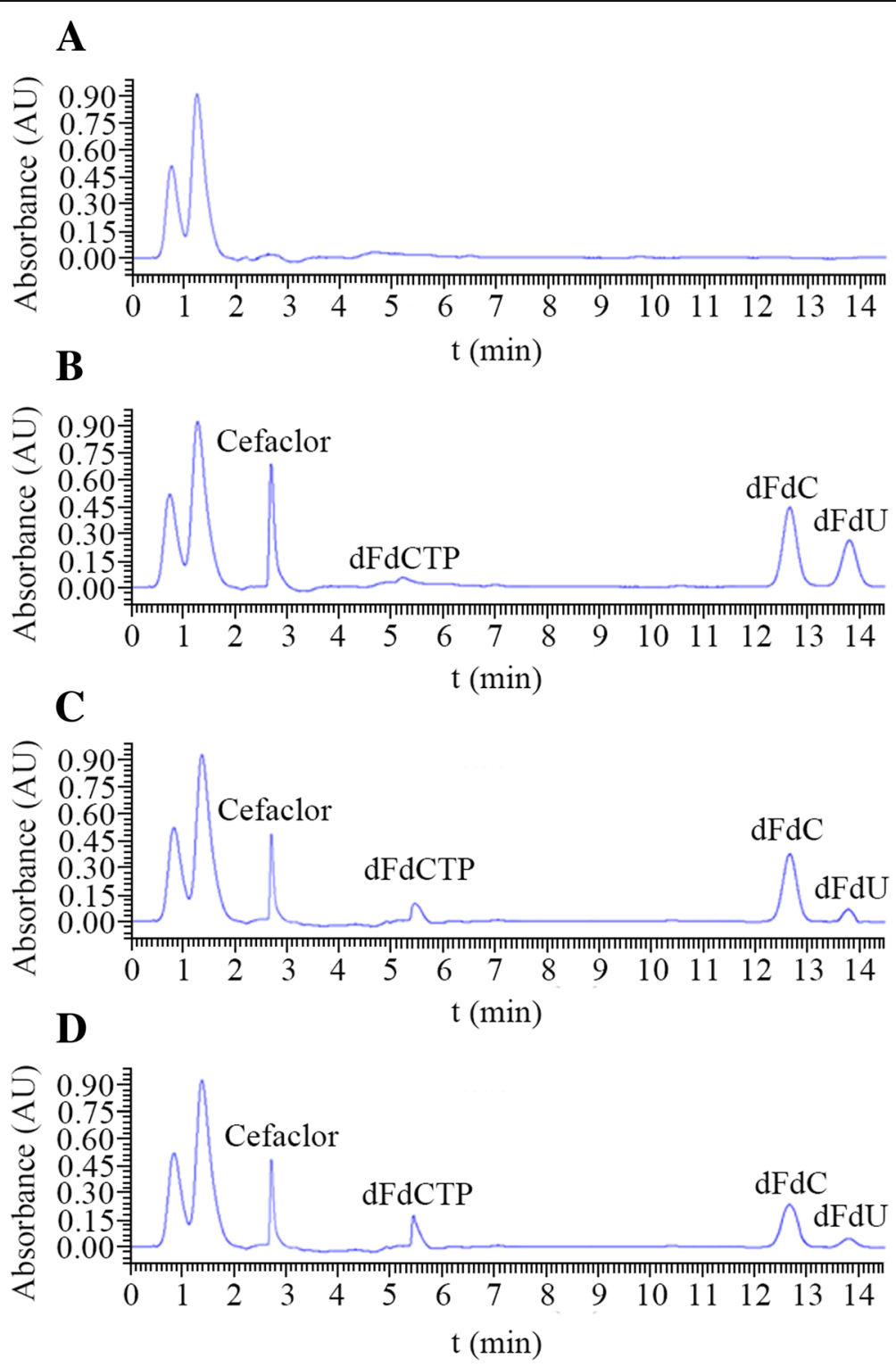

Fig. 4 Representative chromatograms (268 nm) of PANC-1 cell lysates after metabolism under differentconditions of no drugs (a) or loading $\mathrm{dFdC}$ at $I \mathrm{C}_{50}$ along with a heat treatment of $37^{\circ} \mathrm{C}(\mathbf{b}), 41^{\circ} \mathrm{C}$ (c) or $43^{\circ} \mathrm{C}(\mathbf{d})$

the activity of dCKs and this may be viewed as a possible explanation for the rising $\mathrm{dFdCTP}$ level. On the other hand, we consider that a decrease in AFdCTP consumption owing to a reduction in CDA activity and the activation of dCKs by the intermediate of dFdCDP may also partly contribute to the increase in this active substance. Certainly, the definite response mechanism of hyperthermia leading to content variations in $\mathrm{dFdC}$ and its metabolites still needs further exploration.

\section{Conclusions}

In this study, we used an optimized RP-HPLC assay to show that variances in the concentration of $\mathrm{dFdC}$ (gemcitabine) and its metabolites occurred in PANC-1 cells when pretreated with $41{ }^{\circ} \mathrm{C}$ and $43^{\circ} \mathrm{C}$ hyperthermia. We also confirmed that $43^{\circ} \mathrm{C}$ 


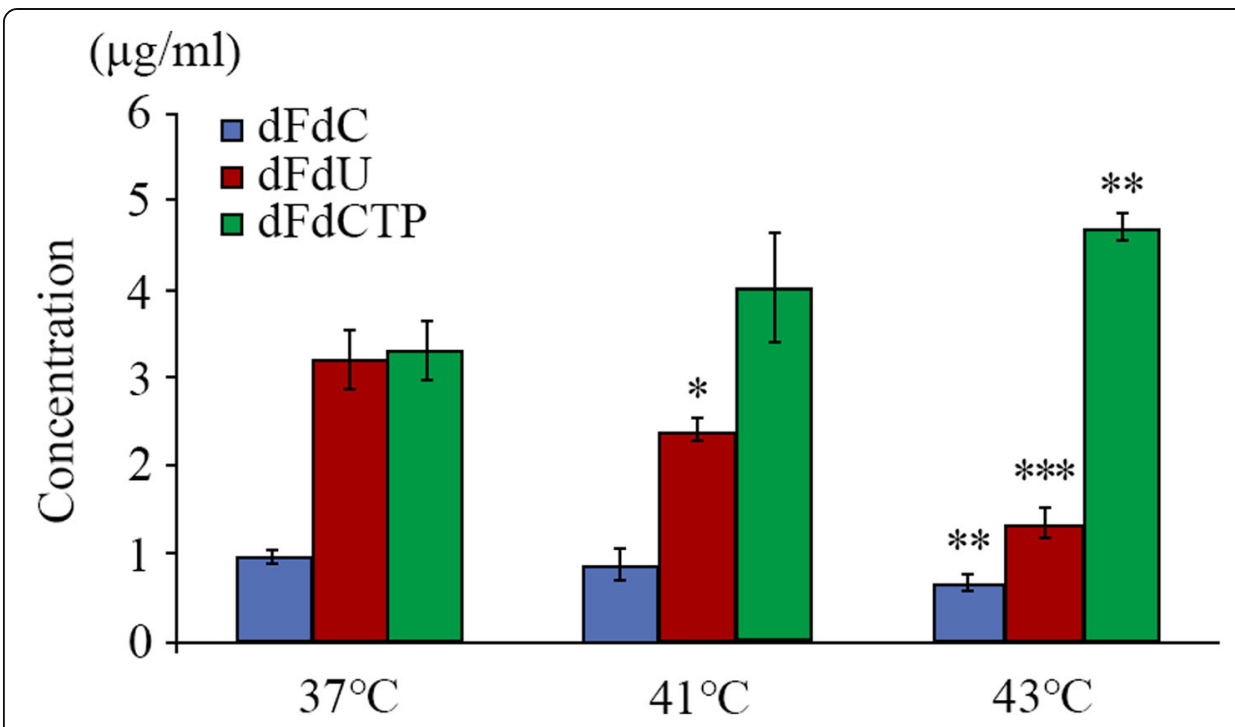

Fig. 5 Effects of hyperthermia on concentration changes in dFdC, dFdU and dFdCTP. Error bars indicate standard errors. $n=5,{ }^{* *} p<0.05,{ }^{* *} p<0.01,{ }^{* * *} p<0.001$

hyperthermiaha sa more significant effect on the drug metabolism. However, the molecular mechanisms leading to the observed effects are still unclear. This initial study of the effects of two heat treatments on $\mathrm{dFdC}$ metabolism should provide a theoretical basis for further research of its pharmacokinetic mechanisms and offer a reference for the best regimen of this combination therapy for pancreatic cancer clinical treatments.

Abbreviations

dCMP: 2'-deoxycytidine 5'-monophosphate; dFdC: 2',2'-difluoro-2'-deoxycytidine, Gemcitabine; dFdCTP: difluorodeoxycytidine triphosphate; dFdU: 2',2'-difluorodeoxyuridine; RP-HPLC: reverse phase high-performance liquid chromatography

Acknowledgements

Not applicable

\section{Funding}

This research was supported by the Hangzhou Science and Technology Development Plan Project (grant number 20162013A01).

Availability of data and materials

Not applicable

\section{Authors' contributions}

HB Jin created the study concept and wrote and edited the manuscript, $L L u$ and $L$ Xie conducted the experiments and collected data, JF Yang and XF Zhang contributed to the writing and prepared the figures, HB Jin and SL Ma provided resources and reviewed the manuscript, and all the authors have read and approved the final manuscript.

Ethics approval and consent to participate

Not applicable

Consent for publication

Not applicable

Competing interests

The authors declare that they have no competing interests.

\section{Publisher's Note}

Springer Nature remains neutral with regard to jurisdictional claims in published maps and institutional affiliations. 
Received: 25 November 2018 Accepted: 25 April 2019

Published online: 16 May 2019

\section{References}

1. Siegel RL, Miller KD, Jemal A. Cancer statistics, 2017. CA Cancer J Clin. 2017;67(1):7-30.

2. Miller KD, Siegel RL, Lin CC, Mariotto AB, Kramer JL, Rowland JH, et al. Cancer treatment and survivorship statistics, 2016. CA Cancer J Clin. 2016;66(4):271-89.

3. Rahib L, Smith BD, Aizenberg R, Rosenzweig AB, Fleshman JM, Matrisian LM. Projecting Cancer incidence and deaths to 2030: the unexpected burden of thyroid, liver, and pancreas cancers in the United States. Cancer Res. 2014;74(11):2913-21.

4. Enewold LHL, Tucker T, McKenzie S. Pancreatic cancer in the USA: persistence of undertreatment and poor outcome. Journal of gastrointestinal cancer. 2015;46(1):9-20.

5. Eppinga W, Lagerwaard F, Verbakel W. Volumetric modulated arc therapy for advanced pancreatic Cancer. Strahlenther Onkol. 2010;186(7):382-7.

6. Ohguri T, Imada H, Yahara K. Concurrent chemoradiotherapy with gemcitabine plus regional hyperthermia for locally advanced pancreatic carcinoma: initial experience [J]. Radiat Med. 2008;26(10):587-96.

7. Konski A, Meyer JE, Joiner M, Hall MJ, Philip P, Shields A, et al. Multi-institutional phase I study of low-dose ultrafractionated radiotherapy as a chemosensitizer for gemcitabine and erlotinib in patients with locally advanced or limited metastatic pancreatic cancer. Radiother Oncol. 2014;113(1):35-40.

8. Burris HA 3rd, Moore MJ, Andersen J, Green MR, Rothenberg ML, Modiano MR, et al. Improvements in survival and clinical benefit with gemcitabine as first-line therapy for patients with advanced pancreas cancer: a randomized trial. J Clin Oncol. 1997;15(6):2403-13.

9. Valsecchi ME, Díaz-Cantón E, de la Vega M, Littman SJ. Recent treatment advances and novel therapies in pancreas cancer: a review. Journal of gastrointestinal cancer. 2014;45(2):190-201.

10. Wickremsinhe E, Bao J, Smith R, Burton R, Dow S, Perkins E. Preclinical absorption, distribution, metabolism, and excretion of an oral amide prodrug of gemcitabine designed to deliver prolonged systemic exposure. Pharmaceutics. 2013; 5(2):261-76.

11. Goldstein D, El-Maraghi RH, Hammel P, Heinemann V, Kunzmann V, Sastre J, et al. nab-Paclitaxel Plus Gemcitabine for Metastatic Pancreatic Cancer: Long-Term Survival From a Phase III Trial. JNCl: Journal of the National Cancer Institute. 2015;107(2):dju413-dju.

12. Von Hoff DD, Ervin T, Arena FP, Chiorean EG, Infante J, Moore M, et al. Increased survival in pancreatic cancer with nab-paclitaxel plus gemcitabine [J]. N Engl J Med. 2013;369(18):1691-703.

13. Zhang DSWD, Wang ZQ, Wang FH, Luo HY, Qiu MZ, Wang F, Li YH, Xu RH. Phase I/Il study of albumin-bound nabpaclitaxel plus gemcitabine administered to Chinese patients with advanced pancreatic cancer. Cancer Chemother Pharmacol. 2013;71(4):1065-72.

14. Suriyanto, EYK N, Kumar SD. Physical mechanism and modeling of heat generation and transfer in magnetic fluid hyperthermia through Néelian and Brownian relaxation: a review. Biomedical engineering online. 2017;16(1):36.

15. van der Zee J. Heating the patient: a promising approach? Annals of Oncology. 2002;13(8):1173-84.

16. Song CW, Park HJ, Lee CK, Griffin R. Implications of increased tumor blood flow and oxygenation caused by mild temperature hyperthermia in tumor treatment. Int J Hyperth. 2005;21(8):761-7.

17. Issels RD. Hyperthermia adds to chemotherapy. Eur J Cancer. 2008;44(17):2546-54.

18. BAKSHANDEH-BATH A, STOLTZ AS, HOMANN N, WAGNER T, STÖLTING S, PETERS SO. Preclinical and clinical aspects of carboplatin and gemcitabine combined with whole-body hyperthermia for pancreatic adenocarcinoma. Anticancer Res. 2009;29(8):3069-77.

19. Tentes A-A, Stamou K, Pallas N, Karamveri C, Kyziridis D, Hristakis C. The effect of hyperthermic intraoperative intraperitoneal chemotherapy (HIPEC) as an adjuvant in patients with resectable pancreatic cancer. Int J Hyperth. 2016;32(8):895-9.

20. Adachi S, Kokura S, Okayama T, Ishikawa T, Takagi T, Handa O, et al. Effect of hyperthermia combined with gemcitabine on apoptotic cell death in cultured human pancreatic cancer cell lines. Int J Hyperth. 2009;25(3):210-9.

21. Guo Y, Ziesch A, Hocke S, Kampmann E, Ochs S, De Toni EN, et al. Overexpression of heat shock protein 27 (HSP27) increases gemcitabine sensitivity in pancreatic cancer cells through S-phase arrest and apoptosis. J Cell Mol Med. 2015; 19(2):340-50

22. Adema AD, Smid K, Losekoot N, Honeywell RJ, Verheul HM, Myhren F, et al. Metabolism and accumulation of the lipophilic deoxynucleoside analogs elacytarabine and CP-4126[J]. Investig New Drugs. 2012;30(5):1908-16.

23. Giovannetti E, Del Tacca M, Mey V, Funel N, Nannizzi S, Ricci S, et al. Transcription analysis of human Equilibrative nucleoside Transporter-1 predicts survival in pancreas Cancer patients treated with gemcitabine. Cancer Res. 2006;66(7):3928-35.

24. Farrell JJ, Elsaleh H, Garcia M, Lai R, Ammar A, Regine WF, et al. Human Equilibrative nucleoside transporter 1 levels predict response to gemcitabine in patients with pancreatic Cancer. Gastroenterology. 2009;136(1):187-95.

25. Ishikawa T, Kokura S, Sakamoto N, Ando T, Imamoto E, Hattori T, et al. Phase II trial of combined regional hyperthermia and gemcitabine for locally advanced or metastatic pancreatic cancer. Int J Hyperth. 2012;28(7):597-604.

26. Affram K, Udofot $\mathrm{O}$, Cat $\mathrm{A}$, Agyare E. In vitro and in vivo antitumor activity of gemcitabine loaded thermosensitive liposomal nanoparticles and mild hyperthermia in pancreatic cancer. Int J Adv Res. 2015;3(10):859-74.

27. Veltkamp SA, Pluim D, van Eijndhoven MA, Bolijn MJ, Ong FHG, Govindarajan R, et al. New insights into the pharmacology and cytotoxicity of gemcitabine and 2',2'-difluorodeoxyuridine. Mol Cancer Ther. 2008;7(8):2415-25.

28. Sugarbaker PH, Stuart OA, Bijelic L. Intraperitoneal Gemcitabine Chemotherapy Treatment for Patients with Resected Pancreatic Cancer: Rationale and Report of Early Data 2011. 7 p.

29. Kumar KK, Nagoji KEV, Nadh RV. A validated RP-HPLC method for the estimation of Lapatinib in tablet dosage form using gemcitabine hydrochloride as an internal standard. Indian J Pharm Sci. 2012;74(6):580-3.

30. Shyam SB, Christian C, Silvia F, Erika Z, Mauro F, Ganesh P, et al. Validated RP-HPLC method for the simultaneous analysis of gemcitabine and LY-364947 in liposomal formulations. Curr Drug Targets. 2013;14(9):1061-9. 
31. Lanz C, Früh M, Thormann W, Cerny T, Lauterburg BH. Rapid determination of gemcitabine in plasma and serum using reversed-phase HPLC. J Sep Sci. 2007;30(12):1811-20.

32. Yonemori $K$, Ueno H, Okusaka T, Yamamoto N, Ikeda M, Saijo N, et al. Severe drug toxicity associated with a singlenucleotide polymorphism of the $<$ em $>$ cytidine deaminase $</ e m>$ gene in a Japanese Cancer patient treated with gemcitabine plus cisplatin. Clin Cancer Res. 2005;11(7):2620-4.

33. Ogawa M, Hori H, Ohta T, Onozato K, Miyahara M, Komada Y. Sensitivity to gemcitabine and its metabolizing enzymes in neuroblastoma. Clin Cancer Res. 2005;11(9):3485-93.

34. Veltkamp SA, Beijnen JH, Schellens JHM. Prolonged versus standard gemcitabine infusion: translation of molecular pharmacology to new treatment strategy. Oncologist. 2008;13(3):261-76.

35. Maréchal R, Mackey JR, Lai R, Demetter P, Peeters M, Polus M, et al. Deoxycitidine kinase is associated with prolonged survival after adjuvant gemcitabine for resected pancreatic adenocarcinoma. Cancer. 2010;116(22):5200-6.

Ready to submit your research? Choose BMC and benefit from:

- fast, convenient online submission

- thorough peer review by experienced researchers in your field

- rapid publication on acceptance

- support for research data, including large and complex data types

- gold Open Access which fosters wider collaboration and increased citations

- maximum visibility for your research: over $100 \mathrm{M}$ website views per year

At $\mathrm{BMC}$, research is always in progress.

Learn more biomedcentral.com/submissions 